\title{
PINE WOOD MODIFICATION BY HEAT TREATMENT IN AIR
}

\author{
Bruno M. Esteves, ${ }^{a^{*}}$ Idalina J. Domingos, ${ }^{a}$ and Helena M. Pereira ${ }^{b}$ \\ Maritime pine (Pinus pinaster) wood has low dimensional stability and \\ durability. Heat treatment was made in an oven using hot air during 2 to \\ $24 \mathrm{~h}$ and at $170-200{ }^{\circ} \mathrm{C}$. A comparison was made against steam heat \\ treatment. The equilibrium moisture content and the dimensional stability \\ (ASE) in radial and tangential directions were evaluated at $35 \%, 65 \%$, \\ and $85 \%$ relative humidity. MOE, bending strength and wettability were \\ also determined. At the same mass loss, improvements of equilibrium \\ moisture content and dimensional stability were higher for oven heat \\ treatment, but the same was true for mechanical strength degradation. A \\ $50 \%$ decrease in hemicellulose content led to a similar decrease in \\ bending strength.
}

Keywords: Bending strength, Dimensional stability, Heat treatment, MOE, Pinus pinaster, Wettability

a: Centre of Studies in Education, Technologies and Health, School of Technology of Viseu, Polytechnic Institute of Viseu, Campus Politécnico Repeses, 3504-510, Viseu, Portugal b: Forest Research Centre, School of Agronomy, Technical University of Lisbon,, Portugal; *Corresponding author:

bruno@demad.estv.ipv.pt

\section{INTRODUCTION}

Heat treatment is a wood improvement and preservation process that is facing a recent surge of interest. Despite having started in 1946 with the work of Stamm et al., it was only in the last decade or so that it was systematically researched and industrially applied in some European countries. There are different commercial heat treatment processes: the Finish process (Thermowood) uses steam (Viitanen et al. 1994), the Dutch (Plato Wood) uses a combination of steam and heated air (Tjeerdsma et al. 1998b), the French (Rectification) an inert gas (Dirol and Guyonnet 1993) and the German (OHT) heated oil (Sailer et al. 2000).

The heat treatment increases the wood value by decreasing equilibrium moisture content (Jämsä and Viitaniemi 2001; Wang and Cooper 2005; Esteves et al. 2007a, b), improving dimensional stability (Viitaniemi et al. 1997; Yildiz 2002; Wang and Cooper 2005; Esteves et al. 2007 a, b) and durability (Dirol and Guyonnet 1993; Kamdem et al. 2002) along with a decrease of the heat transfer coefficient (Militz 2002). The heat treated woods also acquire a darker color similar to most tropical woods, which is an aesthetical advantage for some applications (Mitsui et al. 2001; Bekhta and Niemz 2003). The treatment is however detrimental to mechanical properties especially to static and dynamic bending strength (Yildiz 2002; Esteves et al. $2007 \mathrm{a}, \mathrm{b}$ ), and also to compressive strength (Unsal and Ayrilmis 2005).

When submitted to heating, wood changes its chemical composition through a thermal degradation that depends on temperature and time of exposure. For example, although wood presents a good thermal stability at $100{ }^{\circ} \mathrm{C}$ if the treatment time is long 
enough some chemical bonds begin to break, even for lower temperatures (Shafizadeh and Chin 1976). The temperature at which thermal degradation begins depends also on the wood species. For example, Kollmann and Fengel (1965) concluded that there was only mass loss for temperatures higher than $100{ }^{\circ} \mathrm{C}$ for pinewood, and $130-150^{\circ} \mathrm{C}$ for oakwood. The temperature at which the degradation starts depends on the molecular mass and crystallinity of the wood components (Belville 1982).

Maritime pine (Pinus pinaster) is a low valued timber species because of the relatively poor dimensional stability and durability of pinewood and the difficult preservation which is only possible for small diameters. Additionally it has an unappealing yellowish color. Heat treatment could improve some of these aspects and be a possible alternative to environmentally doomed chemical preservation treatments. The French process has already been applied to treat Pinus pinaster wood.

This paper presents results on the treatment of pinewood describing the properties change along the treatment, the decrease in equilibrium moisture content and increase in dimensional stability, the decrease in wettability and the degradation of mechanical properties mainly of $\mathrm{MOE}$ and bending strength. The selected treatment was heating in hot air at temperatures $170-200^{\circ} \mathrm{C}$ and variable duration leading to different treatment severity. The improvement of properties was related to mass loss. A comparison is made between this treatment and the steam heat treatment reported by Esteves et al. (2007b) in the same conditions, therefore allowing analyzing the effect of an oxidative atmosphere which is likely to induce more intensive chemical changes on wood.

\section{EXPERIMENTAL}

\section{Material and Wood Treatment}

Pinewood samples were cut from the sapwood of a radial board of one maritime pine (Pinus pinaster Aiton.) tree from the Portuguese region of Águeda. Cubic samples with approximately $40 \mathrm{~mm}$ edge and samples with $360 \mathrm{~mm} \times 20 \mathrm{~mm} \times 20 \mathrm{~mm}$ were cut with clear faces, kept in a conditioned room at $20^{\circ} \mathrm{C}$ and $50 \%$ relative humidity for 3 weeks and weighed afterwards. The equilibrium moisture content and the dry mass of the samples were determined. The heat treatment was made in an oven heated by electric coils located in the walls and with exhaustion of the heated gases by natural convection through an opening in the oven wall. The treatment was made for 2 to $24 \mathrm{~h}$ and at 170 $200^{\circ} \mathrm{C}$. The treatment started by putting the samples at ambient temperature in the oven, and the period to reach the treatment temperature was about $60 \mathrm{~min}$. Four replicates were used for each combination of time/temperature of treatment and for each sample size. After treatment, the samples were cooled down in a dry environment and weighed. Mass loss was determined in relation to initial dry wood. Untreated samples were used as the control.

\section{Wood Properties}

Treated and untreated wood samples were kept in a controlled environment at $20^{\circ} \mathrm{C}$ and sequentially equilibrated at 35,65 , and $85 \%$ relative humidity for at least 4 weeks in each relative humidity and until the mass variation was less than $5 \%$ in two 
consecutive days. Mass was determined and the equilibrium moisture content was calculated. The samples dimensions were measured in radial and tangential directions for all the relative humidity and dimensional stability of the heat treated samples was calculated as an Anti Swelling Efficiency (ASE). ASE gives the difference between the swelling coefficient of treated and untreated samples, from oven dry to 35\% (ASE35), $65 \%$ (ASE65) and 85\% (ASE85) relative humidity in percentage of the swelling values

for the untreated samples. For example $\operatorname{ASE}_{35}(\%)=\left(\frac{S_{n t}-S_{t}}{S_{n t}}\right) * 100$

where $S_{n t}$ and $S_{t}$ represent the shrinking between $35 \%$ relative humidity and $0 \%$ relative humidity for untreated (nt) and treated ( $\mathrm{t}$ ) samples. The shrinking is determined in percent as

$\mathrm{S}(\%)=\left(\frac{L_{35 \%}-L_{0 \%}}{L_{35 \%}}\right) * 100$

with $\mathrm{L}$ representing the dimension of the sample.

Wettability was determined by the contact angle method in tangential and radial sections, with the contact angle measured 10 seconds after the contact of a $10 \mu$ water drop with the sample. Distilled water was used in this test.

The mechanical properties were determined with samples of $360 \times 20 \times 20 \mathrm{~mm}^{3}$ (axial $\mathrm{x}$ radial $\mathrm{x}$ tangential) by a three point bending device. MOE measurements were made using a constant velocity of $0.3 \mathrm{~mm} / \mathrm{min}$ and for bending strength the velocity was estimated to cause rupture in about $3 \mathrm{~min}$.

MOE and bending strength were determined according to the Portuguese standard NP-619 as:

$\operatorname{MOE}\left(\mathrm{N} / \mathrm{mm}^{2}\right)=\frac{\Delta F * L^{3}}{\Delta x * 4 * b^{*} h^{3}}$

Bending strength $(\mathrm{MPa})=\frac{3 * F^{*} L}{2 * b^{*} h^{\frac{10}{6}}}$

where $\mathrm{F}$ is the load on rupture measured in $\mathrm{N} / \mathrm{mm}, \frac{\Delta F}{\Delta x}$ is the slope of the elastic zone in $\mathrm{N} / \mathrm{mm}, \mathrm{L}$ is the arm length, $\mathrm{h}$ the height and $\mathrm{b}$ the width, all expressed in $\mathrm{mm}$.

\section{RESULTS AND DISCUSSION}

\section{Mass Loss}

Figure 1 presents the mass loss with heat treatment for temperatures between 170$200^{\circ} \mathrm{C}$ along the treatment time. 


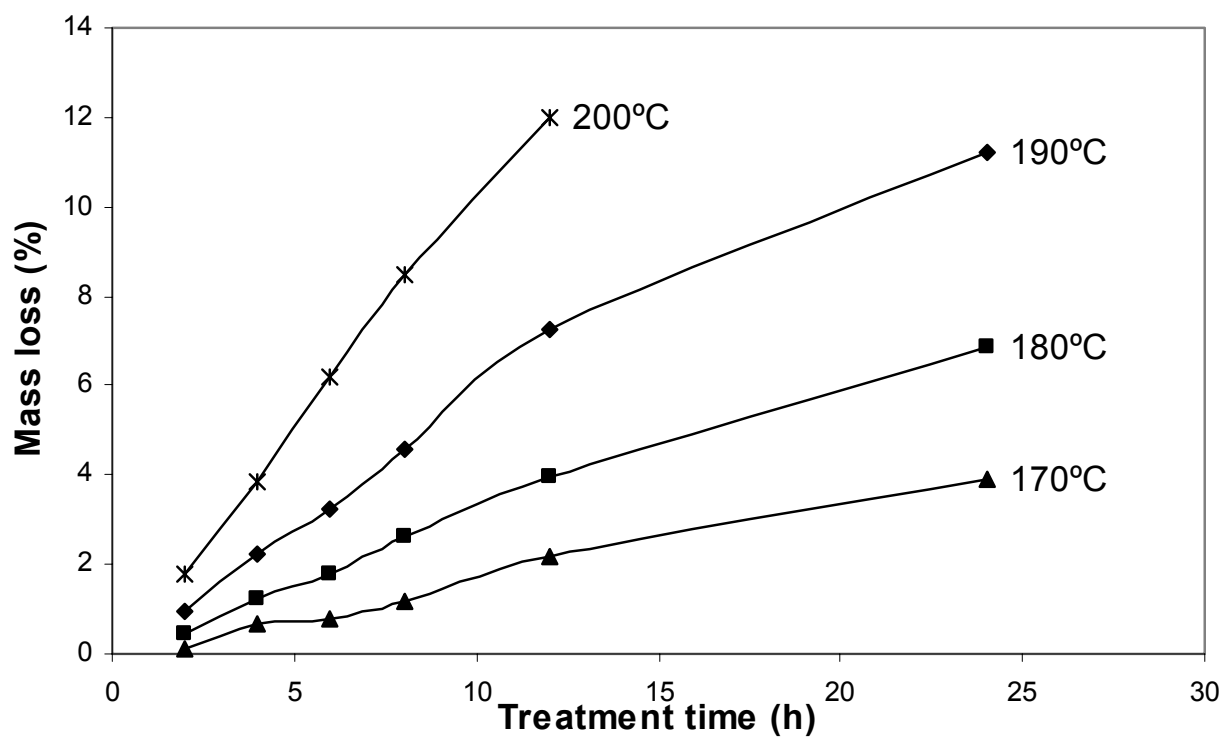

Fig. 1. Pinewood mass loss with heat treatment

Mass loss increased with the treatment time and with the temperature, and the same mass loss could be obtained with different temperatures, depending on the treatment time (Fig. 1). For example, a mass loss of $3 \%$ could be reached at $170^{\circ} \mathrm{C}$ in 17 $\mathrm{h}$, at $180^{\circ} \mathrm{C}$ in $9 \mathrm{~h}$, at $190^{\circ} \mathrm{C}$ in $5 \mathrm{~h}$ and at $200^{\circ} \mathrm{C}$ in only $3 \mathrm{~h}$. Similar results were reported by several authors. For instance, Zaman et al. (2000) treated Pinus sylvestris and Betula pendula at temperatures between $200^{\circ} \mathrm{C}$ and $230^{\circ} \mathrm{C}$ during $4-8 \mathrm{~h}$ and determined that the mass losses for pine varied between $5.7 \%(4 \mathrm{~h})$ to $7.0 \%(8 \mathrm{~h})$ at $205{ }^{\circ} \mathrm{C}$, and between $11.1 \%(4 \mathrm{~h})$ and $15.2 \%(8 \mathrm{~h})$ at $230{ }^{\circ} \mathrm{C}$ and for birch $6.4 \%(4 \mathrm{~h})$ and $10.2 \%(8 \mathrm{~h})$ at $200{ }^{\circ} \mathrm{C}$ and $13.5 \%(4 \mathrm{~h})$ and $15.2 \%(8 \mathrm{~h})$ at $220^{\circ} \mathrm{C}$. Alén et al. (2002) studied the mass loss of heat treated spruce at temperatures between $180^{\circ} \mathrm{C}$ and $225^{\circ} \mathrm{C}$ during 4 to 8 hours and concluded that they were between $1.5 \%$ at $180{ }^{\circ} \mathrm{C}(4 \mathrm{~h})$ and $12.5 \%$ at $225^{\circ} \mathrm{C}(6 \mathrm{~h})$. At higher temperatures mass losses are quite higher; Bourgois and Guyonnet (1988) attained a mass loss of $18.5 \%$ in just 15 min, reaching $30 \%$ for 1 hour for maritime pine wood at $260^{\circ} \mathrm{C}$. Órfão et al. (1999) reported that Pinus pinaster wood starts to degrade at $140^{\circ} \mathrm{C}$ with or without the presence of oxygen.

The rate of mass loss was higher in the beginning of the treatment and decreasing for longer treatments. Since the mass loss showed an approximately linear variation with the treatment time until about $12 \mathrm{~h}$, it was possible to adjust linear equations with statistically significant coefficients $\left(\mathrm{R}^{2}\right.$ between 0.972 and 0.998$)$. The rate of mass loss (in $\mathrm{h}^{-1}$ ) increased with the treatment temperature: $0.20\left(170^{\circ} \mathrm{C}\right), 0.35\left(180^{\circ} \mathrm{C}\right), 0.63$ $\left(190^{\circ} \mathrm{C}\right), 1.03\left(200^{\circ} \mathrm{C}\right)$. The higher initial rate of mass loss was due to the thermal degradation of the more susceptible compounds, mainly hemicelluloses but also to the volatilization of some extractives as reported by Esteves et al. (2007c). For example in a treatment at $190^{\circ} \mathrm{C}$ during $6 \mathrm{~h}$ the hemicelluloses content decreases $17.2 \%$ in relation to the initial content and at the same time most of the original extractive compounds have disappeared (Esteves et al. 2007c). Similar results for the degradation rate were also reported for the heat treatment of other species like cedar (González-Peña et al. 2004). 
Mass loss of oven heat treated pine wood was higher than for autoclave steam heat treated pine wood at the same conditions as reported by Esteves et al. (2007b). As an example, for a treatment at $200{ }^{\circ} \mathrm{C}$ during $6 \mathrm{~h}$ the mass loss for pine wood treated in the oven was $6.2 \%$, while in the autoclave it was only $3.5 \%$ (Fig. 1 ). These results are in accordance with Stamm (1956), who reported that wood degrades more in the presence of air due to oxidation reactions. It is also known that the acetic acid produced in this process acts as a depolymerization catalyst, and it is possible that there is a higher content of acetic acid released on the oxidizing environment. Mazela et al. (2003) compared the mass losses with heat treatment in air or in an atmosphere with water vapor, using temperatures of $160^{\circ} \mathrm{C}, 190^{\circ} \mathrm{C}$, and $220^{\circ} \mathrm{C}$ during $6-24 \mathrm{~h}$ and reported that the mass losses in the presence of air and water vapor for a treatment during 6 hours were similar, but for $24 \mathrm{~h}$ mass losses in air were much higher.

The extent of thermal decomposition is often measured by mass loss. In accordance to the Thermowood patent (Viitaniemi et al. 1997), a mass loss of 3\% is needed to improve wood dimensional stability and at least $5 \%$ to improve durability.

\section{Equilibrium Moisture Content}

The equilibrium moisture content of pine wood decreased with heating even for very short treatment times.

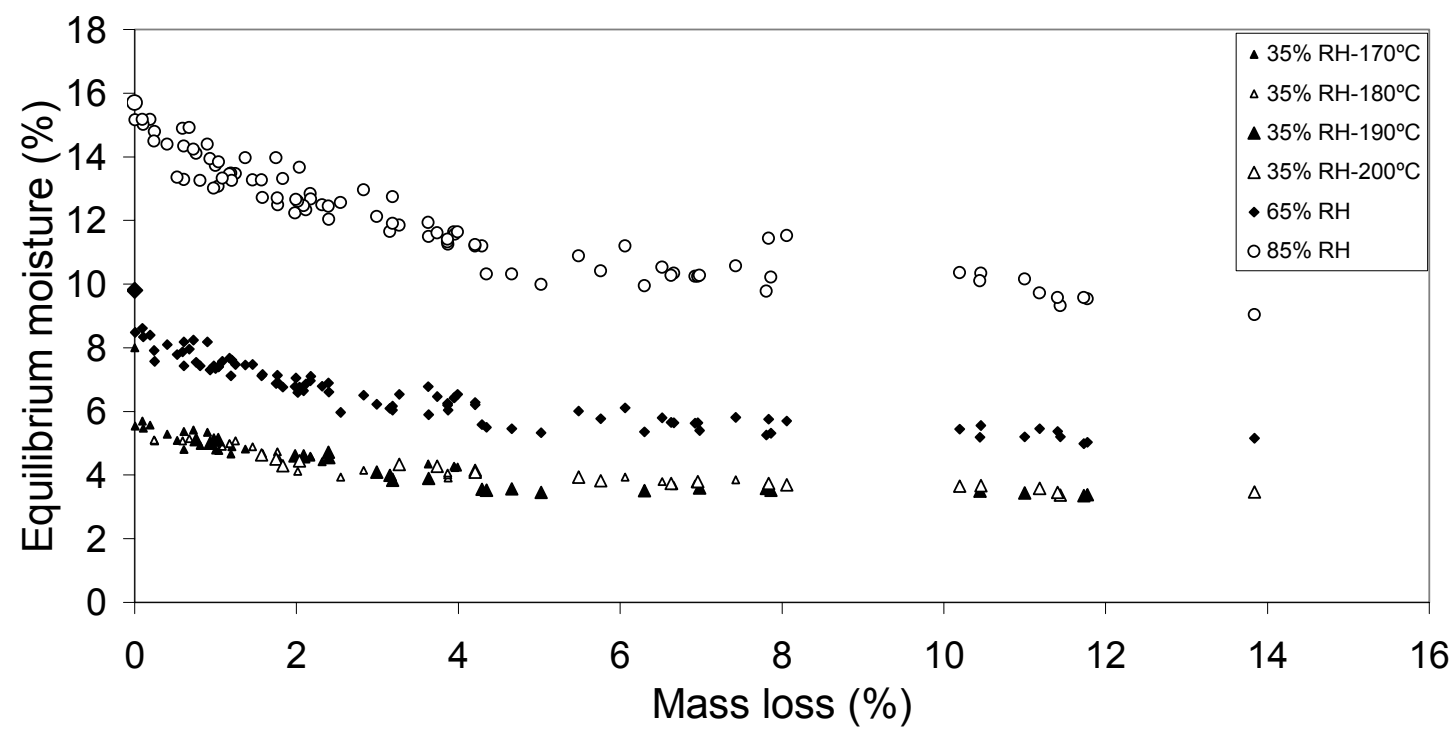

Fig. 2. Equilibrium moisture content of heat treated wood in relation to mass loss in different relative humidity environments.

Figure 2 presents the equilibrium moisture content at three different relative humidities $(35 \%, 65 \%$ and $85 \%)$ as a function of mass loss. The equilibrium moisture content of heat treated pine wood decreased with the increase in treatment severity. The rate of decrease was higher for lower mass loss reaching a minimum value for about $4 \%$ mass loss. The behavior was similar for the three relative humidity environments. Although the net reduction of equilibrium moisture content was higher for $85 \%$ relative 
humidity, the reduction in relation to untreated wood was higher for $35 \%$ relative humidity. These results are generally in agreement with Kamdem et al. (2002) for beech wood treated at temperatures between $200-260^{\circ} \mathrm{C}$ and conditioned at similar relative humidities (66\% and 86\%) and with Esteves et al. (2007a) for eucalypt wood.

A mass loss between $4-6 \%$ was enough to get the maximum reduction in equilibrium moisture and a higher treatment severity did not benefit the equilibrium moisture of wood (Fig. 2). Similar results were reported by Esteves et al. (2007b) with autoclave heat treated pine wood, but in this case the minimum equilibrium moisture content was obtained at about $6-8 \%$ mass loss. This means that for a treatment with steam it is necessary to attain a higher mass loss to have a similar reduction on equilibrium moisture. This is possibly due to the somewhat different degradation reactions with heat occurring in air and in steam environment. Viitaniemi et al. (1997) also reported identical results for spruce wood, with the minimum equilibrium moisture content being reached for about $6 \%$ mass loss.

The reduction on equilibrium moisture content is due to several factors. The degradation of hemicelluloses, which are the most hygroscopic structural compounds, plays an important role but the degradation of the amorphous regions of cellulose and the cross-linking reactions also contribute to the decrease on equilibrium moisture content as reported by several authors (Bhuiyan and Hirai 2005;Tjeerdsma et al. 1998a; Tjeerdsma and Militz 2005). Esteves et al. (2007c) reported that hemicelluloses content decreased $17.2 \%$ and $10.4 \%$ in relation to initial content at about $3 \%$ mass loss for a treatment in air and in steam environment, respectively. A higher mass loss is needed for the steam treatment to attain the same hemicelluloses reduction and consequently a similar effect on equilibrium moisture.

The reasons for the apparent stabilization of the equilibrium moisture content for higher mass losses are not clear, although Bhuiyan and Hirai (2005) refer that cellulose crystallinity decreases for more severe treatments which might increase the accessible hydroxyl groups.

\section{Dimensional Stability}

The heat treatment improved pine wood dimensional stability even for short time treatments, increasing with time and temperature of treatment. For example the radial $\mathrm{ASE}_{35}$ of heat treated wood was $57 \%$ with $8 \mathrm{~h}$ at $170{ }^{\circ} \mathrm{C}, 4 \mathrm{~h}$ at $180{ }^{\circ} \mathrm{C}$ or $2 \mathrm{~h}$ at $190^{\circ} \mathrm{C}$. The maximum values reached were between $63-73 \%$. Similar results were reported by several authors, i.e. Yildiz (2002) with beech wood treated at $130-200^{\circ} \mathrm{C}$ during $2-10$ hours.

The improvements on dimensional stability were higher for lower relative humidities (Fig. 3). For example at 65\% RH, the tangential ASE ranged between 25 and $38 \%$ reaching a maximum of $62 \%$ while for $85 \% \mathrm{RH}$, the maximum tangential ASE was $44 \%$. The increase in dimensional stability is mainly due to the decrease in equilibrium moisture content. 
$190^{\circ} \mathrm{C}$

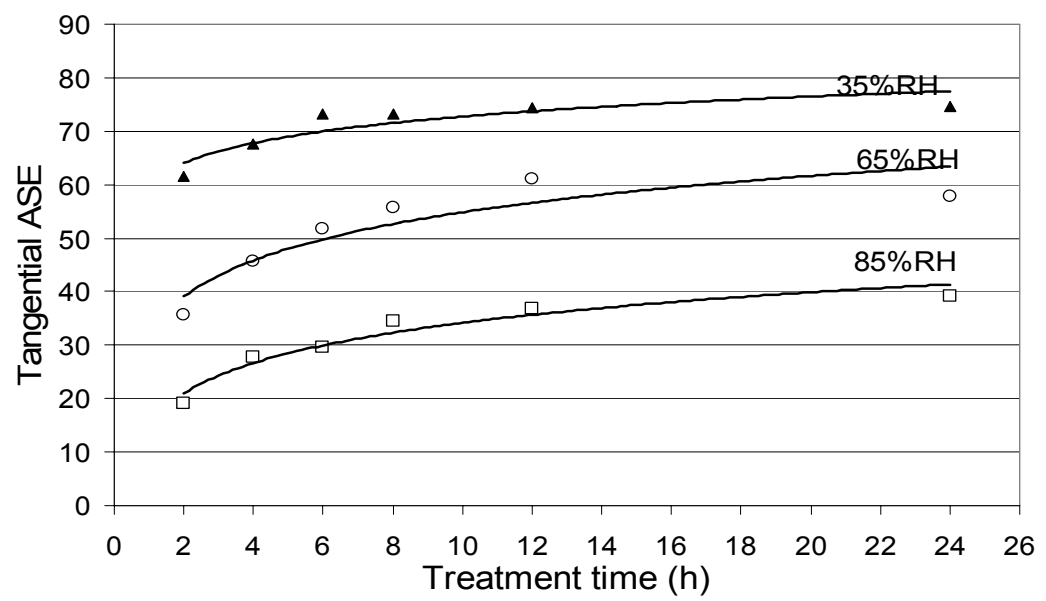

Fig. 3. Relationship between tangential ASE and treatment time for 35,65 and $85 \%$ relative humidity. Each point is an average of 4 samples.

Figure 4 shows the variation of radial and tangential ASE with mass loss, at $35 \%$ relative humidity. The improvements were slightly higher in the tangential direction with $\mathrm{ASE}_{35}$ ranging from 73 to $80 \%$ for treatments at $170-200^{\circ} \mathrm{C}$. Although stability improved more in the tangential direction, the swelling of treated wood samples remained higher than in the radial direction. The behavior was similar for $65 \%$ and $85 \% \mathrm{RH}$. Analogous results were reported by Tjeerdsma et al. (1998a) with beech, birch, spruce, Scots pine and Monterey pine.

For outdoor furniture it is important to have similar radial and tangential swelling, that is to say, a low anisotropy; therefore the decrease in anisotropy with the heat treatment as given by the comparatively higher increase in tangential ASE is an advantage for this type of wood use.

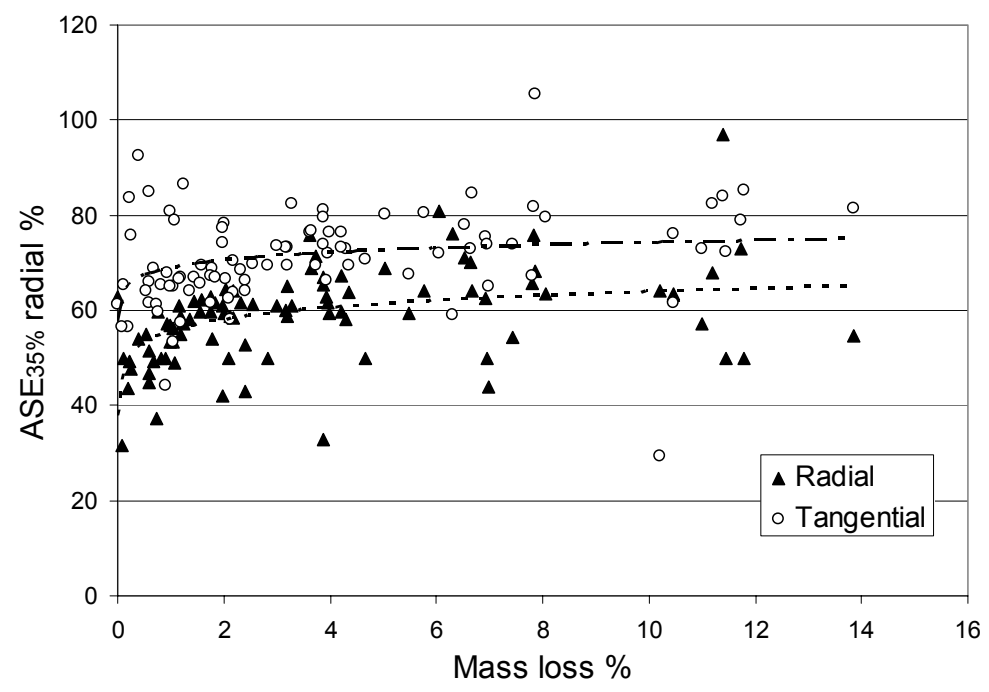

Fig. 4. Variation of radial and tangential ASE with mass loss at $35 \%$ relative humidity 
The increase in dimensional stability was higher for smaller mass losses until about $4 \%$. The results were similar for both directions but with slightly higher values in the tangential direction.

The maximum ASE values were obtained at a mass loss of about $4-6 \%$, and only in a few cases a small increase of dimensional stability was observed for higher mass losses. These results are in accordance with those reported by several authors i.e. Viitaniemi et al. (1997) with spruce wood, in which the maximum ASE was obtained for mass loss between 5-6\% and Esteves et al. (2007b) for autoclave heat treated pine and eucalypt wood for 6-8\% mass loss.

\section{Wettability}

The surface wettability in relation to mass loss for radial and tangential sections is presented in Figure 5. The contact angle increased, and the wettability decreased, until about 3\% mass loss for both sections, and after that stabilized for higher mass losses. Similar results were reported by Pecina and Paprzycki (1988) with Scots pine and Hakkou et al. (2003) with poplar, beech, spruce and Scots pine. The wettability decrease is due to the degradation of the most hygroscopic compounds, hemicelluloses, and amorphous cellulose, but also to dehydratation reactions. The change of the extractive composition might also play an important role on wood wettability. At 3\% mass loss according to Esteves et al. (2007c) most of the original pinewood extractives have disappeared and new ones have been formed. The new extractives formed are mainly some phenolic compounds and anhydrosugars.

An increase of wettability for higher mass losses is possible due to the degradation of macromolecular compounds as mentioned by Pecina and Paprzycki (1988). The differences in extractive chemical composition between $3 \%$ and higher mass losses, reported by Esteves et al. (2007c) could also contribute to a change of wood wettability.

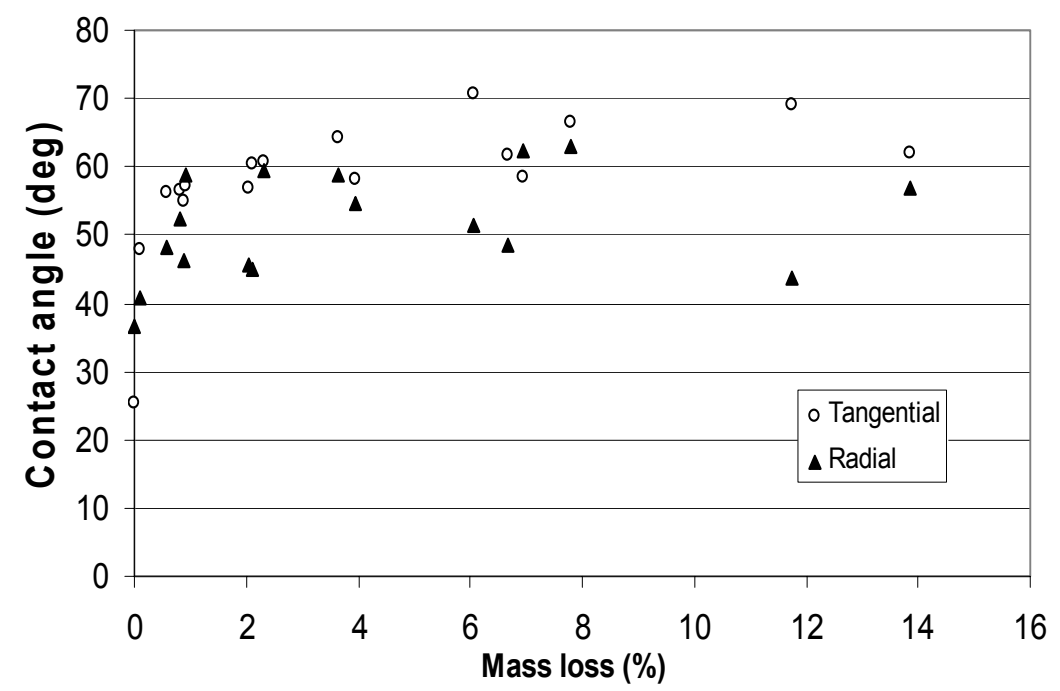

Fig. 5. Contact angle on tangential and radial sections in relation to mass loss during heat treatment . 
Although wettability of untreated pine wood was higher for the tangential section, there were no significant differences between sections for heat treated wood.

Wettability influences gluing and finishing, mainly by increasing the absorption time of glues and varnishes; however, according to Vernois (2000) some varnishes can be adapted to this type of wood.

\section{Mechanical Properties}

MOE and bending strength decreased with heat treatment time and temperature. With $2 \mathrm{~h}$ of treatment, the MOE reduction was very small, with $2 \%\left(180^{\circ} \mathrm{C}\right), 0 \%\left(190^{\circ} \mathrm{C}\right)$, and $0 \%\left(200^{\circ} \mathrm{C}\right)$, and reached $6 \%\left(180^{\circ} \mathrm{C}\right), 12 \%\left(190^{\circ} \mathrm{C}\right)$, and $19 \%\left(200^{\circ} \mathrm{C}\right)$ with $12 \mathrm{~h}$ of treatment. The modulus of elasticity of pine wood decreased with mass loss during the heat treatment (Fig. 6). The decrease was less than 5\% until about $4 \%$ mass loss, but increased subsequently and attained $16 \%$ for about $6 \%$ mass loss. Although the MOE decreased with heat treatment, at the mass loss necessary to obtain the maximum improvement on equilibrium moisture and dimensional stability (4-6\%) the decrease was under $10 \%$ which is not significant. Yildiz et al. (2002) reported a decrease in MOE of about $45 \%$, for beech wood treated at $130-200^{\circ} \mathrm{C}$ for $2-10 \mathrm{~h}$ but mass loss was not referred. Results reported by Esteves et al. (2007b) with steam heat treated pine wood showed a small increase until about 4\% mass loss, followed by a decrease for higher mass losses. With the same treatment conditions, heating time and temperature, the reduction of MOE was higher for the treatment in air and the same happened when comparing at the same mass loss.

Bending strength of untreated pine wood was, on average $154 \mathrm{MPa}$, varying between 138-171 MPa and decreased in the heat treated pine wood samples more than the MOE. The relative decrease of bending strength was between $4-38 \%$ with only $2 \mathrm{~h}$ of treatment at $180-200^{\circ} \mathrm{C}$ and $31 \%\left(180^{\circ} \mathrm{C}\right), 58 \%\left(190^{\circ} \mathrm{C}\right)$, and $58 \%\left(200^{\circ} \mathrm{C}\right)$ with $12 \mathrm{~h}$ of treatment.

The rate of bending strength decrease was higher for small mass losses, about $40 \%$ for $3 \%$ mass loss, decreasing afterwards, but reaching $60 \%$ for mass losses above $6 \%$ (Fig. 6). The reduction of bending strength was higher than the reported by Kim et al. (1988) for radiata pine treated at $180^{\circ} \mathrm{C}$ during $2 \mathrm{~h}$ with a reduction of the modulus of rupture (MOR) of only $21 \%$ for dry wood and $27 \%$ for green wood. Bengtsson et al. (2002) obtained a similar reduction in bending strength of $50 \%$ for spruce wood and $47 \%$ for Scots pine wood treated at $220^{\circ} \mathrm{C}$. The reduction on bending strength is mainly due to the degradation of hemicelluloses. The close relationship between hemicelulose content and bending strength was also reported by several authors (Winandy and Morrell 1993; Winandy and Lebow 2001). For 7\% mass loss only about 50\% of hemicelluloses remained in wood which has a high impact on bending strength (Fig. 6). 


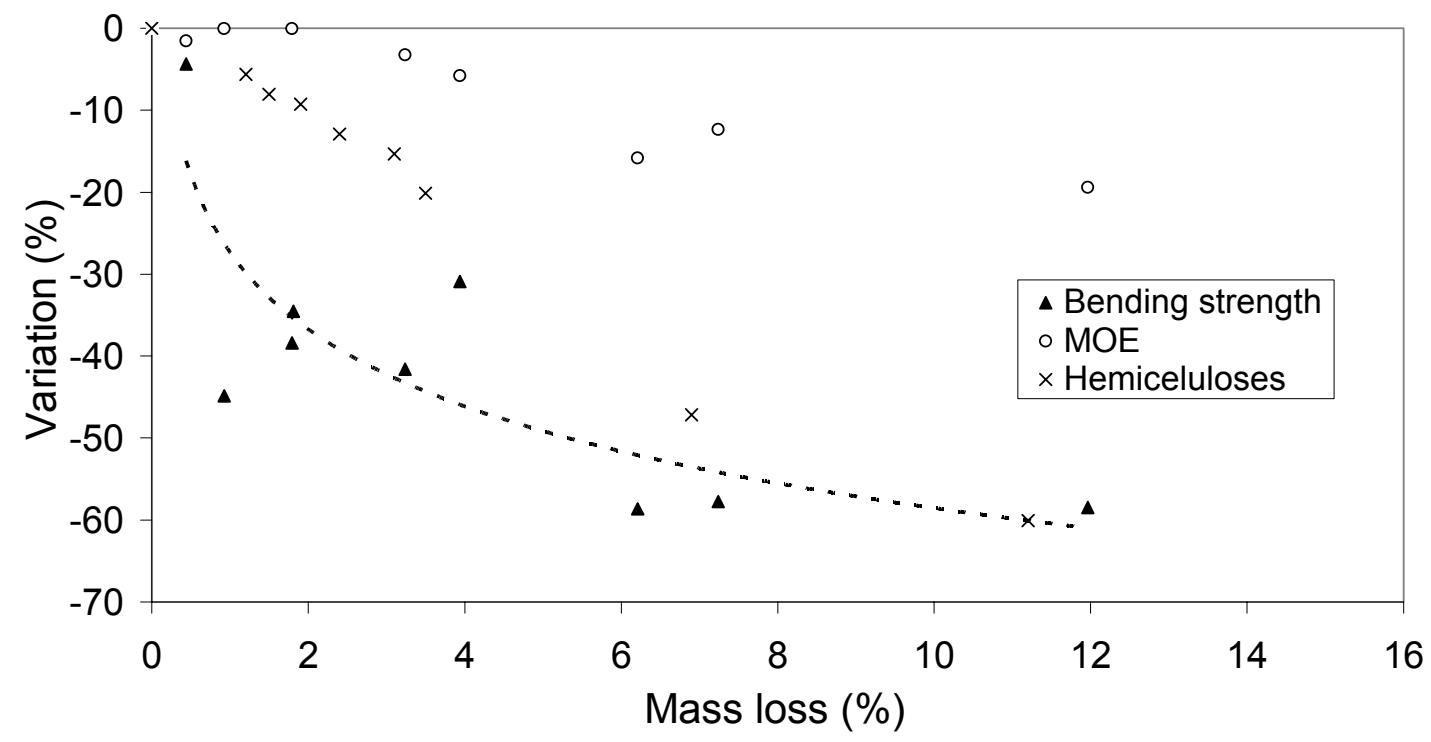

Fig. 6. Variation of bending strength, MOE and hemicelluloses content with mass loss during heat treatment. Each point is the average of 3 samples.

At about (4-6\%) the reduction of bending strength would be about 40-60\% higher than the reported by Esteves et al. (2007b) for steam heat treated pine wood $(25 \%)$. It seems that a treatment with steam affects less the mechanical properties of wood with the same mass loss. Nevertheless, at the same mass loss the degradation of macromolecular compounds is different for wood treated with hot air or with steam. For example, at about $3 \%$ mass loss there is a decrease of hemicelluloses content of $17.2 \%$ and $10.4 \%$ for oven and autoclave treatment, respectively (Esteves et al. 2007c).

\section{CONCLUSIONS}

1. The heat treatment of pine wood improved some of its properties: equilibrium moisture content decreased, the dimensional stability increased, and the anisotropy and the surface wettability decreased. In relation to mechanical properties, MOE was little affected but bending strength decreased much more.

2. Mass loss of oven heat treated pine wood was higher than for steam heat treated pine wood under the same conditions.

3. At the same mass loss the equilibrium moisture content decreased more than for the steam treatment due to the higher degradation of hemicelluloses and amorphous cellulose.

4. The oven heat treatment improved more the dimensional stability but also affected more the mechanical properties of wood than steam heat treatment with the same mass loss, possibly due to the oxidation reactions and to the higher hemicellulose 
degradation. A 50\% decrease in hemicellulose content led to a similar decrease in bending strength.

\section{REFERENCES CITED}

Alén, R., Kotilainen, R., and Zaman, A. (2002). "Thermochemical behavior of Norway spruce (Picea abies) at 180-225 ${ }^{\circ} \mathrm{C}$," Wood Sci. Technol. 36, 163-171.

Bekhta, P., and Niemz, P. (2003). "Effect of high temperature on the change in color, dimensional stability and mechanical properties of spruce wood," Holzforschung 57, 539-546.

Belville, P. (1982). "Modélisation de la cinetique de pyrolyse de particules de bois de taille importante et du bilan matiere de la gazeification à l'oxygene pur," Thesis Université de Compiégne, France.

Bengtsson, C., Jermer, J., and Brem, F. (2002). "Bending strength of heat-treated spruce and pine timber," In: International Research Group Wood Pre, Section 4-Processes, $\mathrm{N}^{\mathrm{o}}$ IRG/WP 02-40242.

Bhuiyan, T., and Hirai, N. (2005). "Study of crystalline behaviour of heat-treated wood cellulose during treatments in water," J. Wood Sci. 51, 42-47.

Bourgois, J., and Guyonnet, R. (1988). "Characterisation and analysis of torrefied wood," Wood Sci. Technol. 22: 143-155

Dirol, D., and Guyonnet, R. (1993). "Durability by rectification process," In: International Research Group Wood Pre, Section 4-Processes, N ${ }^{\circ}$ IRG/WP 93-40015.

Esteves, B., and Pereira, H. (2007c). "Influence of heat treatments in pine wood extractives," Submitted to Journal of Wood Chemistry and Technology.

Esteves, B., Domingos, I., and Pereira, H. (2007a). "Improvement of technological quality of eucalypt wood by heat treatment in air at 170-200 C, " For. Prod. J. 57 $(1 / 2), 47-52$.

Esteves, B., Velez Marques, A., Domingos, I., and Pereira, H. (2007b). "Influence of steam heating on the properties of pine (Pinus pinaster) and eucalypt (Eucalyptus globulus) wood," Wood Sci. and Technol. 41, 193-207. DOI : 10.1007/s00226-0060099-0.

González-Peña, M., Breese, M., and Hill, C. (2004). "Hygroscopicity in heat-treated wood: Effect of extractives," In: International Conference on Environmentally Compatible Forest Products (ICECFOP). 22-24 September 2004. pp. 105-119.

Hakkou, M., Pétrissans, M., El Bakali, I., Gérardin, P., and Zoulalian, A. (2003). "Evolution of wood hydrophobic properties during heat treatment," In: Abstracts of the First European Conference on Wood Modification, Ghent, Belgium.

Jämsä, S., and Viitaniemi, P. (2001). "Heat treatment of wood - Better durability without chemicals," In: Proceedings of special seminar held in Antibes, France.

Kamdem, D., Pizzi, A., and Jermannaud, A. (2002). "Durability of heat treated wood," Holz Roh-Werkst 60: 1-6.

Kim, G., Yun, K., and Kim, J. (1998). "Effect of heat treatment on the decay resistance and the bending properties of radiata pine sapwood," Material und Organismen 32 (2), 101-108. 
Kollmann, F., and Fengel, D. (1965). "Changes in the chemical composition of wood by thermal treatment," Holz Roh Werkst. 12, 461-468.

Mazela, B., Zakrzewski, R., Grzeskowiak, W., Cofta, G., and Bartkowiak, M. (2003). "Preliminary research on the biological resistance of thermally modified wood," In: Abstracts of the First European Conference on Wood Modification, Ghent, Belgium.

Militz, H. (2002). "Thermal treatment of wood: European processes and their background," In: International Research Group Wood Pre, Section 4-Processes, No IRG/WP 02-40241.

Mitsui, K., Takada, H., Sugiyama, M., and Hasegawa, R. (2001) "Changes in the properties of light-irradiated wood with heat treatment: Part 1 Effect of treatment conditions on the change in color," Holzforschung 55, 601-605.

NP 619 (1973)- "Ensaio de flexão estática de madeiras," In Portuguese.

Órfão, J., Antunes, F., and Figueiredo, J. (1999). "Pyrolysis kinetics of lignocellulosic materials- Three independent reactions model," Fuel 78, 349-358.

Pecina, H., and Paprzycki, O. (1988). "Wechselbeziehungen zwischen der Temperaturbehandlung des Holzes und seiner Benetzbarkeit," Holzforsch. Holzverwert. 40(1), 5-8.

Sailer, M., Rapp, A., and Leithoff, H. (2000). "Improved resistance of Scots pine and spruce by application of an oil-heat treatment," In: International Research Group Wood Pre, Section 4-Processes, N IRG/WP 00-40162.

Shafizadeh, F., and Chin, P. (1976). "Thermal deterioration of wood," In: Goldstein Wood Technology Chemical Aspects. ACS Symposium Series, 57-81.

Stamm, A. (1956). "Thermal degradation of wood and cellulose," Ind. Eng. Chem. 48, 413-417.

Stamm, A., Burr, H., and Kline, A. (1946). "Stayb-wood-A heat stabilized wood," Ind. Eng. Chem. 38 (6), 630-634.

Tjeerdsma, B., and Militz, H. (2005). "Chemical changes in hydrothermal wood: FTIR analysis of combined hydrothermal and dry heat-treated wood," Holz. Roh Werkst. 63, 102-111.

Tjeerdsma, B., Boonstra, M., and Militz, H. (1998a). “Thermal modification of nondurable wood species: improved properties of thermally treated wood," In: International Research Group Wood Pre, document No IRG/WP 98-40124.

Tjeerdsma, B., Boonstra, M., Pizzi, A., Tekely, P., and Militz, H. (1998b). "Characterisation of thermally modified wood: molecular reasons for wood performance improvement," Holz Roh-Werkst. 56, 149-153.

Unsal, O., and Ayrilmis, N. (2005). "Variations in compression strength and surface roughness of heat-treated Turkish river red gum," J. Wood Sci. 51, 405-409.

Vernois, M. (2000). "Heat treatment of wood in France-State of the art," Centre Technique du Bois et de l'Ameublement, Paris, France.

Viitanen, H., Jämsä, S., Paajanen, L., Nurmi, A., and Viitaniemi, P., (1994). "The effect of heat treatment on the properties of spruce document $\mathrm{N}^{\circ}$ IRG/WP 94-40032, 4p.

Viitaniemi, P., Jämsä, S., and Viitanen, H. (1997). "Method for improving biodegradation resistance and dimensional stability of cellulosic products," United States Patent $N^{o}$ 5678324 (US005678324). 
Wang, J., and Cooper, P. (2005). "Effect of oil type, temperature and time on moisture properties of hot oil-treated wood," Holz Roh-Werkst 63, 417-422.

Winandy, J., and Lebow, P. (2001). "Modeling strength loss in wood by chemical composition. Part I. An individual component model for southern pine," Wood Fiber Sci. 33 (2), 239-254.

Winandy, J., and Morrell, J. (1993). "Relationship between incipient decay, strength, and chemical composition of Douglas-Fir heartwood," Wood Fiber Sci. 25 (3), 278-288.

Yildiz, S. (2002). "Effects of heat treatment on water repellence and anti-swelling efficiency of beech wood," In: International Research Group Wood Pre, Section 4Processes, No IRG/WP 02-40223.

Zaman, A., Alen, R., and Kotilainen, R. (2000). "Thermal behavior of Pinus sylvestris and Betula pendula at 200-230 ${ }^{\circ}$ C," Wood Fiber Sci. 32 (2), 138-143.

Article submitted: July 17, 2007; Peer-review completed: Aug. 26, 20007; Revised version received and approved: Jan. 3, 2008; Published Jan. 5, 2008. 